
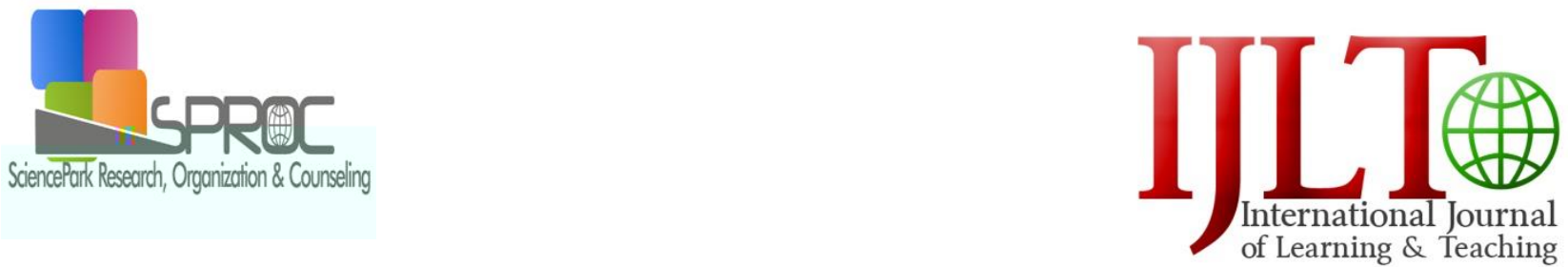

www.ij-It.eu

\title{
Creating a positive learning environment for adults
}

Amal Roshdi A.Mostafa

Suggested Citation

Abstract

Amal Roshdi A.Mostafa

$D$ 
1. Introduction

D 
“

2. Method 
Table 1. Tool (2)

3. Field Work

4. Ethical Consideration 
5. Limitation of the Study

$R$

6. Results 


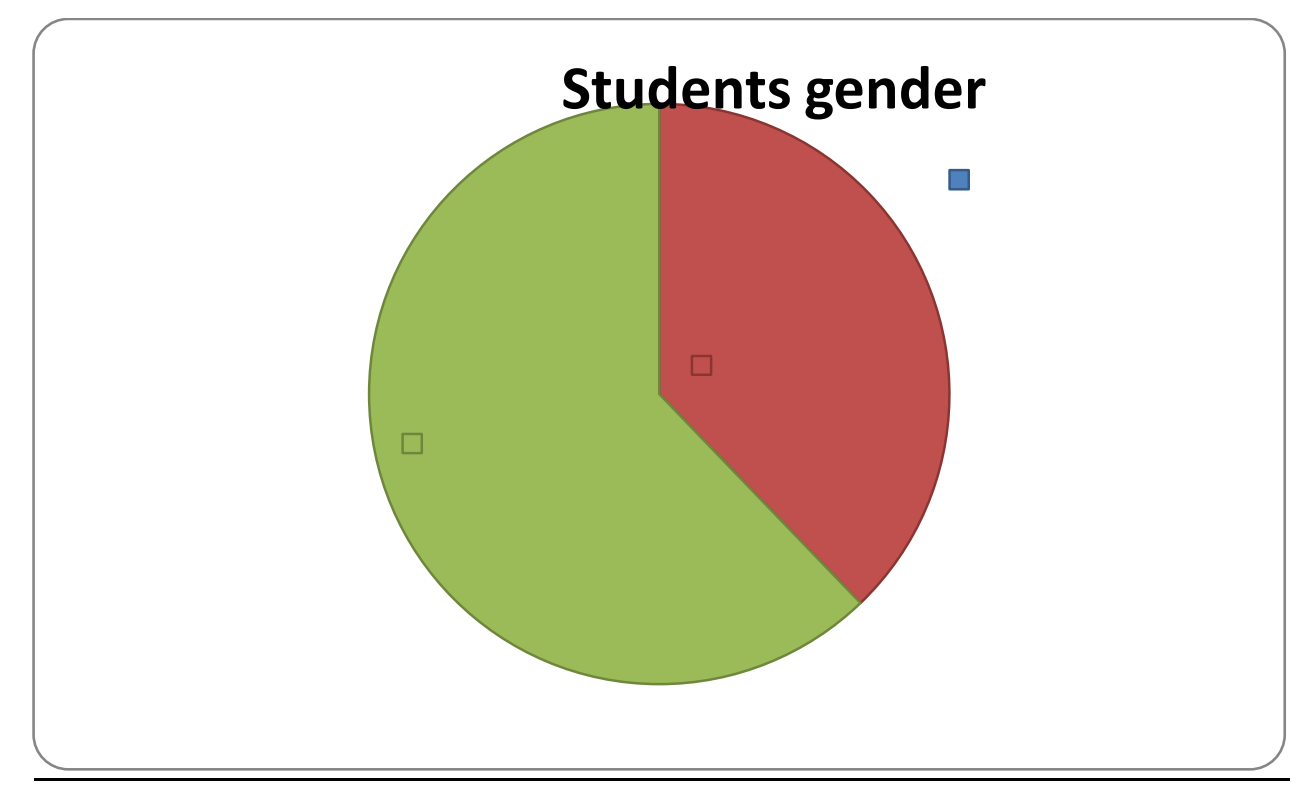

Students Grade

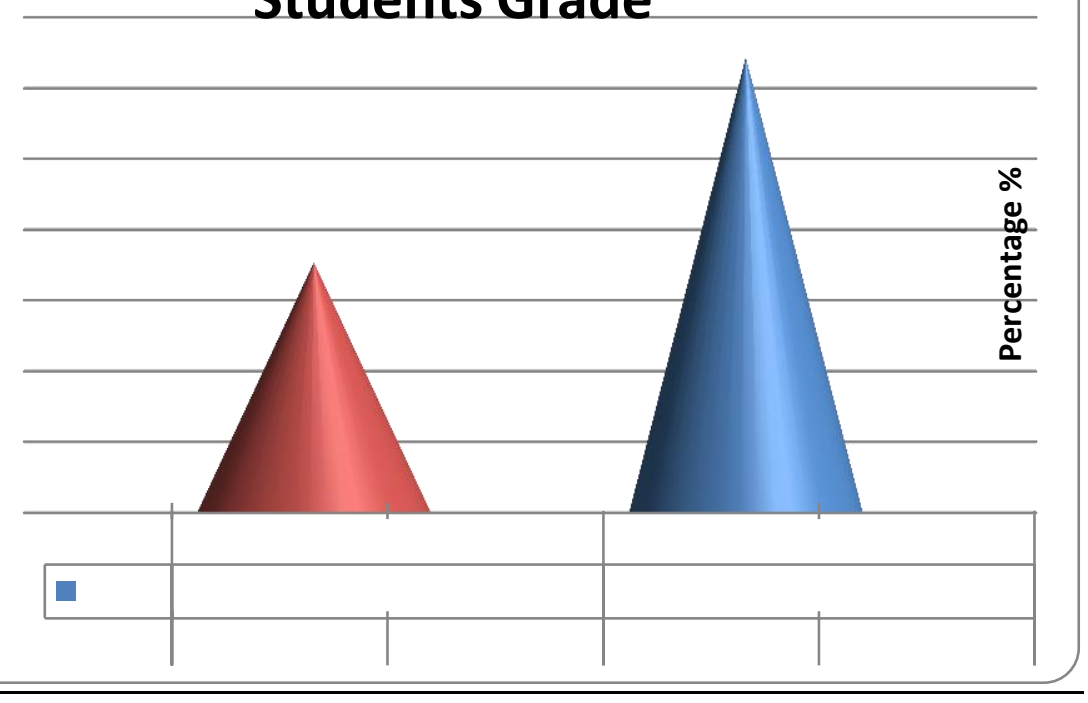


Table 1. The CLEl assessment scores for nursing students

7. Discussion 
8. Conclusion 
9. Recommendations for Future Research

\section{References}

D

$T$

$R$

D

$R$

D

D

D 
